\title{
Nawa Sanga Conspiracy: Secrets Behind Ancient Balinese Emblem of Unity
}

\author{
An Ethnographic Study
}

\author{
Ida Bagus Arya Lawa Manuaba \\ English Education Department \\ STKIP Suar Bangli \\ Bangli, Indonesia \\ tharsisfactor@yahoo.com
}

\author{
Ida Ayu Made Istri Utami \\ English Education Department \\ Universitas Pendidikan Ganesha \\ Singaraja, Indonesia \\ istriutami@undiksha.ac.id
}

\begin{abstract}
The aims of the study were (1) to track the origin of Nawa Sanga symbolism in ancient Balinese society, (2) to discover the history behind the usage of Nawa Sanga symbolism, and (3) to analyze the actual philosophy of Nawa Sanga symbolism to the ancient Balinese. The research design used was descriptive-qualitative with ethnographic method which mainly involved the analysis of cultural aspects in ancient Balinese religious texts and chronicles. Data range involved prominent Balinese ancient religious texts and babad (chronicle texts). Data collecting techniques used were document analysis and observation. The result of the study showed that (1) the Nawa Sanga symbolism in ancient Balinese society came from the Saivite teachings dating in the same period as Majapahit Empire fell down, (2) the Nawa Sanga symbolism was formulated during the Waturenggong period to politically unify the Balinese society, and (3) the actual philosophy behind Nawa Sanga symbolism was not religious, but political.
\end{abstract}

Keywords—Nawa Sanga, Balinese society, babad.

\section{BACKGROUND}

As long as Balinese culture is concerned, it still provides vast field of research ranging from its antiquity from the purwa 'ancient, earlier' era to its ongoing post-modern date [1]. Since Majapahit Empire fell down in the last quarter of the fifteenth century [2], Bali had become the only neighboring country for the exodus and survival of the ancient Javanese culture from invasion of the new politics and ideology.

Through closer observation, however, Balinese culture apparently has a lot of exceptional features in comparison to Javanese culture from which it derived its basic Hindu philosophy for more than 1500 years [3]. The concept and symbolism of Dewata Nawa Sanga, for instance, were practically absent in Javanese earlier literature period up to the fall of Majapahit Empire. Surprisingly, this concept had been highly regarded as a theological apprehension and emblem by the Balinese Hindus [3] began from the early sixteenth century, not long after Javanese domination ended. The absence of this theological thought in Javanese Hindu culture and its gaining majesty in Bali in almost the same era marked a very essential question regarding its true indigenous origin.

Research on the origin of Dewata Nawa Sanga concept is another challenging field of study on Balinese culture. This unique theological idea has emerged for at least five centuries in Bali only and still remains almost untouched by scientific methods, though some Balinese modern scholars have managed to conduct studies on it. Starting its milestone from this point, this research had three main goals. First, it aimed to track the origin of Dewata Nawa Sanga concept in Bali from the literature basis. Further, this study revealed the reason for the emergence of this concept and emblem in the medieval Balinese Hindu society. At last, this study concluded its analysis on the actual philosophy derived from the Dewata Nawa Sanga symbolism.

\section{CONCEPTS}

\section{A. Nawa Sanga}

Etymologically, Nawa Sanga comes from two words. The former is a Sanskrit term meaning 'nine' and the latter is its synonym in old Javanese language. However, some scholars tended to assume the later as a different word sangga, an old Javanese word synonymous to the verb 'to sustain' or 'to support' in English [4]. The word dewata in the beginning of the phrase indicates that of divinity, deities, or worshipable personalities. Thus, dewata nawa sang $(g) a$ generally means 'nine sustaining deities'.

This concept of nine protecting gods were firstly found in Wrihaspati Tattwa and Sundarigama, two prominent medieval Balinese Hindu theological texts of the fifteenth century [5]. Succeeding authors later adopted this concept to subsequent scriptures belonging to the same genre such as the Bhagawan Garga, Kanda Pat Dewa, Tutur Tapini, Bhuwana Kosa, Siwagama and so on as well as other genres such as kidung and macapat hymns which developed in the later century.

The Dewata Nawa Sanga has become the basic principle of Balinese Hindu theology at least since the Waturenggong period (1460-1550 AD) [5][6]. Prior to this period, according 
to [7] and [3], Balinese literature pre-developed from a linguistically different modes and genres. The Dewata Nawa Sanga concept had been widely accepted by the Balinese royal orders and commoners starting from Waturenggong period to the present era. The Kusuma Dewa scripture, compiled during Waturenggong period, provided strong evidence of this assumption in relation to the gods' respective temples and their locations. Later, when the kingdom of Bali disintegrated into eight smaller semi-independent territories in the seventeenth century, minor amendments, versions and supplementary texts to the scripture informed slightly different names of temples where the nine gods were resided.

Since then, Balinese Hindu cultural elements rooted their ideas from Dewata Nawa Sanga symbolism. The Kanda Pat Dewa scripture (which is not elaborately discussed in this research) mentions detailed attributes and paraphernalia of the nine gods. The arrangement is as follows.

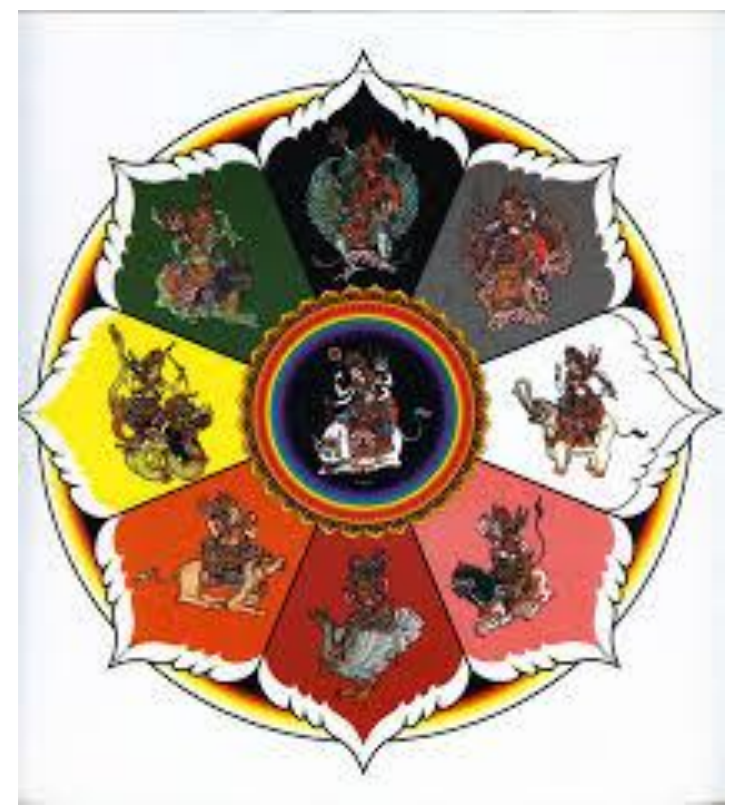

Fig. 1. Symbol of Dewata Nawa Sanga (image courtesy: Paramita Publisher, Surabaya, 2002).

$\begin{array}{ll}\text { Direction } & : \text { pürwa 'east' } \\ \text { Presiding deity } & : \text { Iśwara } \\ \text { Color } & : \text { White } \\ \text { Sacred syllable } & : \text { Sa } \\ \text { Celestial weapon } & : \text { wajra 'bell' } \\ & : \text { agneya 'south east' } \\ \text { Direction } & : \text { Mahésora } \\ \text { Presiding deity } & : \text { Pink } \\ \text { Color } & : \text { Na } \\ \text { Sacred syllable } & : \text { dhupa 'incense' } \\ \text { Celestial weapon } & : \text { dakșina 'south' } \\ & : \text { Brahmā } \\ \text { Direction } & : \text { Red } \\ \text { Presiding deity } & : \text { Ba } \\ \text { Color } & \end{array}$

Celestial weapon

Direction

Presiding deity

Color

Sacred syllable

Celestial weapon

Direction

Presiding deity

Color

Sacred syllable

Celestial weapon

Direction

Presiding deity

Color

Sacred syllable

Celestial weapon

\section{Direction}

Presiding deity

Color

Sacred syllable

Celestial weapon

Direction

Presiding deity

Color

Sacred syllable

Celestial weapon

\section{Direction}

Presiding deity

Color

Sacred syllable

Celestial weapon
: gada 'club'

: Nériti 'south west'

: Rudra

: Orange

: Ma

: mośala 'two sided club'

: paścima 'west'

: Mahadewa

: Yellow

: Ta

: nagapaśa 'serpent arrow'

: wayabhya 'north west'

: Śankara

: Green

$: \mathrm{Si}$

: à்kuśa 'fiery arrow' (though originally means a stick to control elephant).

: uttara 'north'

: Wișnuu

: Black

: A

: cakra 'disc'

: airsanya 'north east'

: Śambhu

: Grey

: Wa

: triśula 'trident'

: madhya 'center'

: Siwa

: combination of white, black, red and yellow.

: I and Ya

: padma 'lotus'

The nine gods were believed, according to the Sundarigama scripture, as manifestation of the Supreme God to protect the universe. The positions of the gods were later put into a symbol known as padma bhuwana 'the universal lotus' [see Figure 1] with eight petals representing eight directions and one in the middle as the ninth, where Lord Siva resided. The position of Lord Siwa as the pivot of the lotus suggested that this symbolism derived its basic principles from Sivaism philosophy, the major Hindu sect in Bali since Waturenggong era [8].

\section{B. Balinese Literature}

A range of complexity follows definition of Balinese literature. Basically, it is defined as any literary works originating from Bali, ranging from its first known history to the present [9]. However, studies by prominent Dutch archeologists and historians such as [10], [3] and [9] argued 
that Balinese indigenous and 'pure' literature did not significantly develop prior to and during Majapahit domination. In the other words, before 1343 A.D. when Majapahit Prime Minister Gajah Mada conquered the last standing Warmadewa dynasty in Bali, Balinese literature was not put into prominence. During Warmadewa period (circa 810-1343 A.D.), Bali imported notable resources of religious texts from the Javanese authorities. In the twelfth century, Bali's religious conducts were administered from Medang Empire in East Java, ruled by Airlangga, who had a tight family relationship to Balinese royal order. At this time, the order still preserved its original textual language in Sanskrit, although some observable infiltration of old Javanese words were present in some inscriptions and literary works. In the later century, when many more ancient Vedic texts in Sanskrit language were translated and re-compiled into old Javanese language and poetic styles, more old Javanese texts were imported to Bali and became a part of Balinese literature.

Until 1343 A.D., therefore, Balinese literature was defined as being united with ancient Javanese literature due to tight royal relationship. Any literary works in the form of kakawin metrical verses and Sanskrit texts (later known as sruti texts by modern category) are classified as sekar agung 'great (literary) blossom'. This classification is made later in the modern era [7]. Later, when another type of prose developed during late Majapahit era (the fifteenth century, to be more precise) in the form of unmetered free-style proses (as how a novel is written), it is still categorized as sekar agung. This type of prose is known as palawakya, written mainly in old Javanese language, with some Sanskrit sentences noting the beginning of a new paragraph.

Thus the sekar agung type is actually not an original Balinese literary products. After the fall of Majapahit, however, when the palawakya free writing style developed separately both in Bali and Java, it is still categorized as sekar agung based on the language used. The kakawin tradition, in which a piece of writing is strictly limited by amount of syllables and some other metrical rules, is actually an adoption of ancient Vedic meters used in Sanskrit texts.

In the 1400s, two local genres of literature developed in Java: kidung and macapat. Kidung is a metrical prose written in medieval Javanese language [7]. This genre was also developed in West Jawa, a mysterious but notable fact which needs further notices. The difference in language brings kidung into another type of literature called sekar madhya 'middle-sized (literary) blossom'. This kidung tradition also grew in Bali in the same period, written in medieval Balinese language, a newer dialect version of old Javanese language used by the Balinese in the 1400s to 1600s [11]. Unlike former literary genres, kidungs are mostly anonymous. They are chanted in slow and melancholic style up to this era in temple festivals and formal competitions, being an integral part of religious conducts in Bali. All kidungs are regarded as sacred and are sung only for religious purposes.

In the seventeenth century, macapat style gained popularity as a new literary genre both in Bali and Java. This style had actually been created in Java and brought to Bali in the late 1400s by Dang Hyang Nirartha, a prominent Javanese
Hindu priest who came to Bali in 1498, according to some babad chronicles. Macapat is another metrical poetry, consisting of many types of meters but written and sung in late Balinese and Javanese languages, understandable to modern audience without being translated as the former literature styles were. Macapat is categorized as sekar alit 'light and small (literary) blossom' in Balinese literary nomenclature. In this period only, since macapat metrical poems were written and chanted in late Balinese language, some scholars regard it as semi-indigenous to Bali.

\section{Babad chronicle}

There are more than fifty major babad chronicles being preserved today in Pusat Dokumentasi Provinsi Bali (Bali Documentation Center). The amount could definitely swell if all minor chronicles were compiled from many geriyas (Balinese Hindu priest's houses), puris (ancient palaces) and more places. Babads are proses, written in old Javanese language (with several dialects and code mixings, of course, indicating their origin and date of compilation) containing genealogy of certain remarkable families contributing to the administration of the kingdom in the past [7]. As a source of information about Bali's ancient era, babads are considered as one of important historical data sources and records after inscriptions [1].

\section{THEORETICAL AND EMPIRICAL REVIEWS}

\section{A. Ethnography}

Ethnography is described as a detailed description and interpretation of a culture [12]. It has been used as one of five major qualitative traditions namely biography, phenomenology, ground theory, case study and ethnography. This type of research is also known as naturalistic research or qualitative inquiry since it tried to observe detailed phenomenon occurring it its natural condition.

Many scholars have been arguing whether ethnography is a theory or description. A theory is an analysis of facts and their relation to one another. It is also defined as general principles of a body of facts. However, [13] clarifies that ethnography is not merely a description of something, but it is a theory of how a vivid description should be and how it should involve dynamic flow of intellectual process. Etnography, therefore, is included in one of most popular theories as well as method in qualitative research. This theory is applicable in all field of science. For instance, [14] conducted an ethnographic research on ESL, focusing on common writing mistakes made by an ESL student during a semester. An ethnographic research about inbreeding marriage system in Bayung Gede village, district of Kintamani, Bali was conducted as in [15]. He observed carefully on the way marriage process was conducted and the taboos around that particular marriage system.

Since ethnography is related to cultural group, it deals with a vivid description about cultural elements of a particular ethnic group. Seven cultural elements listed by [16] namely language, system of livelihood (economy), system of knowledge, system of technology, social organization, system of religion, and arts. Ethnographic study includes access and 
depictions into any of the seven elements, either collaboratively or individually.

\section{B. Theory of Power}

As in [17], a propose theory of power in 1959, which was then published in their book a year later, listed five forms of power as follows:

\section{1) Coercive power}

The examples of coercive power were well-established in the colonial and imperialism period, where a group of people forced another group of people to follow them and do something with threats. Bullies are real example of this kind of threatening power.

\section{2) Reward power}

Someone can gain power if he can give other people something they want. The basic principle of this kind of power is that someone do something for someone else and (s)he gets the reward. This can also be a kind of harm if (s)he cannot fulfill the command.

\section{3) Legitimate power}

It is a legal power to control people. A king or a president has a legal power, and so does a manager of a company. This legal power is obtained due to social norms that oblige people to follow. Legitimate power could be a result of a coercive power, for instance when a king conquers a colony, the colony is submissive to him.

\section{4) Referent power}

This form of power is also known as the power of charisma. People follow a person due to his/her charisma. Celebrities and social figures have this kind of power of attraction.

\section{5) Expert power}

Someone gains power because (s)he knows something that other people do not. His/her knowledge and skills make $\mathrm{him} /$ her gain power. The example is a priest or a traditional healer in Bali is regarded powerful because he knows metaphysical things that common people cannot perceive.

Several interesting research have been conducted within the topic of Dewata Nawa Sanga. Nitiasih did a comparative study on the meanings of colors in Dewata Nawa Sanga symbolism [18]. She utilized Natural Semantic Meta-language and universal meaning to describe Balinese people's conception about colors in Dewata Nawa Sanga. Meanwhile, in different discipline, Suastika observed the relation between Dewata Nawa Sanga and tourism in Bali [19]. He proposed nine kinds of tourism adopted from the characteristics of each presiding directional gods in the symbol. Recently, Wirakesuma found that each godly characters in Dewata Nawa Sanga brings visual expression that can be reinterpreted in Balinese contemporary arts [20]. A lot of online articles and book chapters, mainly in [8], 1974), [3], [1], [7], and [5] discuss about Dewata Nawa Sanga as an integral and core segment of Balinese religious system up to this era.

\section{RESEARCH METHODS}

The object of the study was Dewata Nawa Sanga concept which now had become the basis of Balinese Hindu religious conducts. To track the origin of this concept, relevant data was firstly collected through observation and literature study. The data was obtained from ten major babad chronicles depicting Balinese religious concepts from time to time, began since early Balinese period in the ninth century. Data triangulation was obtained from previous research conducted by previous scholars in this field of study. Some other Balinese religious texts were also studied to confirm the validity of the data.

In order to reveal the actual purpose of the Dewata Nawa Sanga concept, further literature study is needed. First, from the development of the Nawa Sanga concept from different eras, ranging from its basic notions to the 'revolutionized' style, a parallel line could be traced and matched with Bali's political, religious and social situation in the coresponding eras. The connection was then interpreted based on the theory of power. The analysis in this stage would reveal how Nawa Sanga concept is tightly related to the power of the kingdom's authority.

Tracing the meaning or ideology behind the Nawa Sanga concept was the ultimate goal of this study. To do so, the symbolism was analyzed based on the historical background in relation to the cultural elements. Textual analysis across time and data resources were used to gain the meaning behind it.

\section{FINDINGS}

\section{A. Origin of Dewata Nawa Sanga}

Careful research on Balinese literature both in the purwa 'ancient, earlier' era (prior to 1300 A.D.), medieval era (1300 to 1600 A.D.) and hanyar 'late' era (after 1600 A.D.) concerning on the philosophy of Dewata Nawa Sanga suggested that this concept was absent in the purwa era and suddenly emerged in the medieval era when most babad chronicles were composed, particularly during the reign of Waturenggong [10]. This gave clue that Dewata Nawa Sanga is not an ancient product of Balinese Hindu teachings since it was conformed in the later period.

The next question drove the analysis on the origin of Dewata Nawa Sanga prior to the medieval period. To do this, careful readings and analysis on several major babad chronicles could support with strong evidence where the Dewata Nawa Sanga was originated from.

Most major babad chronicles describe ancient happenings that formulate the beginning of the history in Bali. Uniquely, those chronicles mostly start from the Saka era 0, indicating that it is the event horizon of Balinese history. This account, however, cannot be regarded as scientifically and historically true since most Balinese literary works include many kinds of traditional metaphors, similes and any other types of figurative language in relation to dates, astronomical calculations and social interaction. Those major babad chronicles depicting general situation and history of ancient Bali always start from the life of demigods as the ancestors of mankind. Fortunately, 
this chronicles of the demigods could help researchers to find the silver line of the connection between the ancient Balinese Hindu theological philosophy and the later period.

There were ten major babad chronicles studied for this purpose. These babad chronicles were selected carefully based on the scope of the chronology. Those chronicles depicting accounts began from how Bali's primeval past was manifested in the history fell to the first category. Meanwhile, some other babad chronicles do not extend their historical range to the beginning of the local genesis. Instead, they commence their plot from a certain event in which their founding genealogical history is firstly brought to importance. These babab chronicles are of the second category. The well-known chronicle records Usana Bali, Usana Bali Pulina and Kusuma Dewa are of the first group and prominently put into main consideration whenever Bali's ancient history is being discussed among historians and traditional interpreters. Other babad chronicles belonging to this group are Babad Pasek, Babad Pasek Kayu Selem, Babad Pasek Sapta Rsi, and Babad Bhujangga. They practically tell the beginning of the genesis of Bali civilization in almost the same way, although there are some insignificant differences in the point of views. Then, there are Babad Brahmana, Babad Brahmana Siwa, Babad Brahmana Catur, and Babad Darmayatra Dang Hyang Nirartha as samples of the second group. Some of these texts do tell some accounts about the ancient family line of olden Javanese kings (who are considered to be originated from Jambudwipa, or India). However, the depiction is relatively short and vague. The second group focused their discourse on the activities and descendants of brahmana lineage in Bali beginning from Dang Hyang Nirartha, a Javanese Hindu brahmana priest who came to Bali in 1498 to propagate revolution in the Balinese Hindu teachings and society under the patronage of King Waturenggong.

Analysis on both groups of babad chronicles show that dewata nawa sangga concept emerged in the Waturenggong period, in the beginning of the $16^{\text {th }}$ century. Actualy, this period can be classified as one segment subsidiary to Dalêm era [1] when Bali was ruled by a dynasty originated from Dalêm Krêsna Kêpakisan in the 1343 A.D. and all his royal descendants were honored by the title dalém 'the deep majesty'. Before Waturenggong period, philosophy of trimurti predominated the religious affairs of the Balinese [5]. Seen from Babad Mpu Kuturan text, this concept emphasizes on the worship of Hindu trinity, Lord Brahmā, Lord Vișnu and Lord Siva. From the Udayana era, this trimurti concept had been widely spread throughout the island via political and cultural vehicles of trihita karana, three causes of prosperity. King Udayana, reigned in the $12^{\text {th }}$ century, along with his chief priest, Mpu Kuturan, a Vaisnava priest from East Java, designed major reformation in the cultural and social structure of the Balinese society. Based on the trimurti concept, the king instructed every village to establish three main temples namely the Pura Desa, or Pura Balé Agung (a sanctuary for Lord Brahma), Pura Pusêr or Pusêh for Lord Vișnu, and Pura Dalêm for Lord Śiva. This trimurti concept is still practiced today by all Balinese traditional pakraman villages. Even when Dewata Nawa Sanga concept was promoted by Dang Hyang Nirartha four centuries later, the trimurti concept is still highly appreciated as the basic foundation of Balinese Hindu religious skeletal pattern.

\section{B. Original Vedic Version of the Nine Gods}

Tracing the analysis of Dewata Nawa Sanga through the platform of time, it arrived to the original concept of nine gods in the Sanskrit Vedic holy texts, developing in India. While Dewata Nawa Sanga puts Lord Siva in the middle (described in the following section as a sign of Sivaism cult), the original version of the nine gods put Lord Brahma in the middle, surrounded by eight prominent gods and thus known as the asta dikpalakas (eight guardian gods of directions).

\begin{tabular}{|c|c|}
\hline Direction & : pūrwa 'east' \\
\hline Presiding deity & : Indra, the rain god \\
\hline Direction & : agneya 'south east' \\
\hline Presiding deity & : Agni, god of fire \\
\hline Direction & : dakșiṇa 'south' \\
\hline Presiding deity & : Yama, the superintendent of death \\
\hline Direction & : Nériti 'south west' \\
\hline Presiding deity & : Niruti, the lord of the ancestors \\
\hline Direction & : paścima 'west' \\
\hline Presiding deity & : Waruna, the deity of water \\
\hline Direction & : wayabhya 'north west' \\
\hline Presiding deity & : Wāyu, the deity of air \\
\hline Direction & : uttara 'north' \\
\hline Presiding deity & : Kuwerra, the treasurer of the gods \\
\hline Direction & : airsanya 'north east' \\
\hline Presiding deity & : Iśana \\
\hline Direction & : madhya 'center' \\
\hline Presiding deity & : Brahmā, the chief of the demigods \\
\hline
\end{tabular}

Apparently, Dewata Nawa Sanga took basic directional principles on dikpalaka concept in the original (and authoritative) concept as per the Vedas, the revealed Holy Scriptures of the Hindus.

\section{The First Seven Local Gods}

The Babad Pasek and Babad Pasek Sapta Rsi chronicles contain interesting account about seven gods which can be grouped as 'the first seven gods prior to Dewata Nawa Sanga'. It is mentioned in the texts that firstly there was a catastrophe in Bali. The sea was rumbling and the island was unstable due to the absence of central divine pivots. Then, Bhatara (god) Paśupati, a primordial god, delegated his three divine children to stay in Bali and thus balance the island from disasters. The eldest was known as Bhatara (god) Putrajaya, resided on Mount Agung. His younger brother, Bhatara Gênijaya, 
resided on Mount Lempuyang, east Bali. The youngest was a goddess named Bhatari (goddess) Danu. She chose to stay on Mount Batur. Then, Bhatara Paśupati delegated four more gods to become gods of directions. They were Bhatara Tugu, resided on Andakasa Hill; Bhatara Manik Galang, resided in Pejeng, Bhatara Tumuwuh on Mount Watukaru, and Bhatara Manik Gumawang on Mount Mangu. Thus they all formed the first seven guardian gods of the Balinese pantheon.

\section{Nine Different Sects}

In the later centuries, many sects developed in Bali. [10] states nine major sects in Balinese Hindu society from the twelfth to the sixteenth century:

1) Vaisnava or Vaisnavism, groups of Visnu worshippers. They are known as the Hariwangsa or Wisnukula since the Majapahit era.

2) Śiwa Siddhanta, Śiwa worshippers.

3) Ganapatya, followers of Ganapati, or Ganesha.

4) Paśupata, they worship another manifestation of Lord Siwa.

5) Buddha (Sogata), followers of Buddhism.

6) Tantra Bhairawa. A tantric follower worships śakti, or Durgā, the cosmic energy.

7) Sakti (Durga), similar to the bhairawa. Sakti followers, however, are known as the white bhairawa since they practice austerities and penances, whereas the black bhairawa indulge themselves in sensual pleasure.

8) Brahmana-smarta, a traditional ritualistic sect.

9) Surya, or saurya, worshipper of Surya, the sun-god.

These nine sects had different ways of life, rituals and core cults and often caused riots. According to [10] and [21] due to this differentiation in sects and cults, Balinese society was practically divided into social and religious sectors and groups and thus led them to fragile communities in the $13^{\text {th }}$ to the first quarter of $16^{\text {th }}$ century.

\section{E. The Nirartha Revolution}

Political chaos in the Majapahit Empire started from 1407 A.D. brought significant decrease on the kingship and society. Due to unstable government and weak policies for a century later, Majapahit fell down from its heydays, invaded by Demak, a newly-growing sultanate in the northern shore of East Java. In 1498, Dang Hyang Nirartha, one of the last priests of the Hindu priesthood order in Java, sailed to Bali in the exodus era when important Javanese Hindu cultural heritage was migrated to Bali due to the chaos [22]. Learning great and painful lesson from the chaotic end of the great kingdom, he tried to save kingdom of Bali from the same terrible fate. His conclusion was, based on the fact, the society must be united to form a strong fortress against the invaders. As a priest, a respected order in the ancient Hindu society, almost at the same position as the king, he managed to commence a revolution in the Balinese society.

Fistly, he came to Gelgel in 1490 and gained sympathy from King Watureggong. The tactic was, when the king instated him as a leading priest of the Balinese royal and common society, he could get the control over the religious affairs in the island.

As a religious society, the ancient Balinese put trust on the authority of the king as dewaraja 'godly king', a representative of God on Earth. The king, however, does not have absolute power. Vedic kingly order is supervised by priesthood order, or the brahminical order [23]. A priest cannot govern the society directly, but a king can. Thus by synchronized powers between the king (politicaladministrative power) and the priest (religious power), the society is maintained in justice, religiousness and prosperity.

By administering these dual powers, Dang Hyang Nirartha formulated the concept of Dewata Nawa Sanga to embrace all Hindu sects in Bali at that particular time into a single ideology of political-religious oneness.

\section{F. Purposes of Dewata Nawa Sanga}

The political and cultural background of the Dewata Nawa Sanga emergence clearly shows that the concept was formulated to politically and culturally unite all sects in Bali at that time. In ancient Balinese society, there were two mutual powers to control the society: the political and religious authorities. When the dual powers take control of the society, design and apply policies, the society will follow. If somebody could gain these two positions, then they could gain power and control over the whole society. This fact was realized by Dang Hyang Nirartha, and to unite Balinese society within a strong cultural and religious citadel, he initiated the king and gained position in the kingdom's priesthood order.

The concept of dewaraja, regarding a king as a representative of gods, and the purohita, the high priest as being regarded as good as god, brought the society into a religiously controlled minds over legitimate power obtained from expertise and charisma of the king and the high priest. Actually, this could have brought peace and ease of control over the people and thus accommodated better management. This situation was deliberately utilized by Dang Hyang Nirartha (who understood the chaotic condition in Java) to protect Balinese society from political, religious and cultural destruction. By utilizing his influence and knowledge as a priest, he gained Waturenggong's affinity and admiration so the king officially instated him to the position of royal high priest and teacher. As he became officially recognized, he formulated an ideology so as to unite all sects in Bali to gain unified power against rapid oversea invasion, both military and cultural.

It is stated in Babad Wisnu Wangsa scripture, that formerly Vaisnavism was one of major sects in Bali, and the bhujangga waisnawa brahminical clans were instated as high priests from the olden times, even prior to the era of Majapahit conquer over Bali in 1343. Due to emergency political situation that demanded society's unity far more urgent than individual cults among religious sects, the supremacy of Vaisnavism was positioned as linear to other sects by the king. Dang Hyang Nirartha and King Waturenggong, however, realizing the great merit and honor to the Vaisnavism, put Lord Wisnu in the northern side of the Dewata Nawa Sanga symbolism (which 
actually does not correspond to any Vedic injunctions). When the symbol is put vertically, Lord Visnu is always put in the top of the symbol, heading towards horizontal north, and Lord Brahma is put at the bottom of the symbol, heading to south in horizontal view. Apart from Lord Brahma and Visnu, all other names of the gods are derived from Lord Siva's names, indicating strongly that the symbol is supported by Siwaistic philosophy. The unique presence of Lord Visnu and Brahma (the main deities of Vaisnavism) is a symbol of high respect from the royal authority to the former glory of Vaisnavism in Bali as well as remembrance of Trimurti worship which had formerly been introduced throughout the island.

By putting all the deities in parallel positions and respective temples, all sects in Bali were united in one ideology, - the Dewata Nawa Sanga ideology. As Indonesia's Pancasila ideology acts as Indonesian people's unification basis from which all national laws and regulations come, all subsidiary religious, cultural and political rules and conducts in the kingdom of Bali emerged from Dewata Nawa Sanga emblem. Newly compiled and modified scriptures were introduced to the people at that time, and modified teachings were taught to generations. Therefore, many essential medieval scriptures known to Balinese society today are compiled as if unsystematically arranged, unlike kakawin verses and slokas (Vedic metrical verses) which were compiled long centuries before. This is a conspiracy, but a very positive one. This conspiracy had been proven extremely effective to protect Bali from outer invasion for about five hundred years.

\section{G. A Strong Religio-Political Conspiracy}

The Balinese culture and religion as people can see today is a result of a clever conspiracy of an ancient genius mind. The Nawa Sanga conspiracy resulted in a significant change in the society, bringing Balinese society into a new perspective. Even though, based on the analytical study of the scriptures and babad chronicles, Nawa Sanga is actually a religiopolitical idea, or a religious concept united to support political affairs, it resulted in amazingly positive effect.

From the form, names and the position of the gods in the emblem, the Nawa Sanga concept contains four basic pillars of ideology. First, it is a cultural and political modification of the original Vedic asta dikpalaka concept, resulting directional-based lotus pattern. Second, Nawa Sanga is a continuation of the previous belief about the nine guardian gods in the preceding era according to Babad Pasek and Babad Pasek Sapta Rsi chronicles. Third, Nawa Sanga concept is imbued with Sivaism concept in which seven of nine names of gods were names of Lord Śiva. This Sivaism concept was dominant in Javanese society in that period, and was later brought to Bali by the priesthood order. Fourth, the two deities, Lord Visnu and Brahma, who are still adopted in the Nawa Sanga emblem, were of previous Vaisnavism sect who flourished in Bali prior to Dang Hyang Nirartha and contributed highly to the religious, cultural and social aspects of the Balinese. To honor the greatness of Vaisnavism, Visnu and Brahma are included in the Nawa Sanga emblem together with Lord Siva and thus constitutes the three principal trimurti gods.

\section{CONCLUSION AND IMPLICATIONS}

Nawa sanga is an example of how an ancient society is brought into a unified ideology for a greater importance. The ideology was formulated to anticipate oversea invasion, a major problem at that time. For a society to continue developing, changes and modification are always needed. Otherwise, the society will be vanquished by a stronger one, either culturally or politically. This concept brings about a conclusion that in order to exist, a society must be alert on any threats, be adaptable to changes, and be ready for further innovation.

For about five centuries, Bali has become an island on which Hindu culture and cults from the previous kingdoms developed and survived. Nawa sanga is a great political innovation which is based on a strong religious foundation of the Balinese society. Thus, it is a very powerful combination between religion and politics which result in a strong cultural foundation for the society. Until then, people can still adopt many things from Balinese culture and tradition, but still it maintains its pivot in the concept of unity in diversity, the Nawa Sanga conspiracy. Departing from this concept, Balinese society should develop and grow further to reply to the challenges of cultural erosion as well as to maintain its cultural and religious uniqueness.

\section{References}

[1] Willard A. Hanna, Bali Chronicles. New York: Periplus Edition, 2004.

[2] Slamet Mulyana, Tafsir Sejarah Nagarakretagama, Yogyakarta: LKIS, 2006.

[3] A.J. Bernet Kempers, Monumental Bali, Singapore: Periplus Edition, 1991.

[4] Zoetmulder, S.O. Robson, Kamus Jawa Kuna-Indonesia, Jakarta: Gramedia Pustaka Utama, 1995.

[5] I Wayan Ardika, Sejarah Bali, dari Prasejarah Hingga Modern, Denpasar: Udayana University Press, 2013.

[6] Ida Bagus Gede Triguna, Mengapa Bali Unik, Jakarta: Pustaka Jurnal Keluarga, 2011.

[7] Zoetmulder, Kalangwan, Selayang Pandang Sastra Jawa Kuno, Jakarta: Djambatan, 1983.

[8] R. Goris, Ancient History of Bali. Denpasar: Faculty of Letters Undayana University, 1965.

[9] S.O. Robson, "Pengkajian sastra-sastra tradisional Indonesia," Jurnal Bahasa dan Sastra, Year IV no. 6, Pusat Pembinaan dan Pengembangan Bahasa, Departemen Pendidikan dan Kebudayaan, 1978.

[10] R. Goris, Sekte-Sekte di Bali. Jakarta: Bhratara, 1974.

[11] Helen Creese, "The Balinese kakawin tradition: a preliminary description and inventory," Bijdragen tot de Taal-, Land- en Volkenkunde, 155 1: 45-96, 1999.

[12] J.W. Creswell, Qualitative Inquiry and Research Design; Choosing Among Five Traditions, London: Sage Publications, 1998.

[13] Laura Nader, Ethnography as Theory, in Journal of Ethnographic Theory 1 (1), University of California, pp. 211-219, 2011.

[14] Mohsine Bensaid, "Ethnographic study: motivation, socialization and writing proficiency," International Journal of Education and Human Developments, Ashland University, Ohio, USA, Vol. 1 no. 1, 2015. 
[15] I Nyoman Sudirman, I Nengah Sueca, I Putu Mariana, "Perkawinan ala binatang, studi kasus perkawinan sedarah pada masyarakat Desa Bayung Gede, Kecamatan Kintamani, Kabupaten Bangli," unpublished.

[16] Koentjaraningrat, Pengantar Ilmu Antropologi. Jakarta: Aksara Baru, 1985.

[17] Sarlito W. Sarwono, Psikologi Sosial (Psikologi Kelompok dan Psikologi Terapan). Jakarta: Balai Pustaka, 2005.

[18] Putu Kerti Nitiasih, "Konsep warna dalam Dewata Nawa Sanga (studi komparasi makna budaya, makna berdasarkan metabahasa semantik alami dan makna universal)," Ganesha University of Education, Singaraja, 2010.

[19] I Made Suastika, Calon Arang dalam Tradisi Bali: Suntingan Teks, Terjemahan, dan Analisis Proses Pem-Bali-an, Yogyakarta: Duta Wacana University Press, 2007.

[20] I Nengah Wirakesuma, "Ekspresi wajah reinterpretasi visual di balik karakter Dewata Nawa Sanga," Jurnal Seni Budaya ISI Denpasar, Vol. 32, no. 1, February 2017, pp. 99-109.

[21] I Gusti Ayu Surasmi, Jejak Tantrayana di Bali, Denpasar: Bali Media Adhikarsa, 2007.
[22] Irawan Djoko Nugroho, Majapahit Peradaban Maritim, Jakarta: Suluh Nuswantara Bakti, 2010.

[23] A.C. Bhaktivedanta Swami Prabhupada, Srimad Bhagavatam (Canto 1), Mumbai: Bhaktivedanta Book Trust, 2002.

[24] IR Made Suastika, "Metamorphosa-based tourism Bali "Dewata Nawa Sanga," Journal of Tourism, Hospitality and Sports Vol. 8, Sebelas Maret University, Surakarta, 2015.

[25] James P. Supradley, Metode Etnografi, Yogyakarta: Tiara Wacana, 1987.

[26] John Hartley, Cultural and Media Studies: The Key Concepts (Third Edition), London: Routledge, 2004.

[27] R. Kapoor, Ancient Hindu Society Volume 1 and 2, New Delhi: Cosmo Publications, 2002.

[28] Richard L. Thompson, The Cosmology of the Bhagavata Purana: Mysteries of the Sacred Universe, Delhi: Motilal Banarsidass Publishers, 2000.

[29] Sir R. Blackwood, Beautiful Bali, Sydney: Rampen Hall, 1970.

[30] S. Hall, Culture, Media, Language, London: Routledge in association with the Centre for Cultural Studies University of Birmingham, 1992. 